Yuliia V. Baklazhenko

Candidate of Pedagogical Sciences, Associate Professor at the Department of English for Humanities \#3 National Technical University of Ukraine "Igor Sikorsky Kyiv Polytechnic Institute", Kyiv, Ukraine ORCHID ID 0000-0002-9035-7737

julia_pavlovska@ukr.net

Tetiana L. Savchuk

teacher at the Department of English for Humanities \#3

National Technical University of Ukraine "Igor Sikorsky Kyiv Polytechnic Institute”, Kyiv, Ukraine

\title{
ENGLISH LANGUAGE LEARNING NEEDS ANALYSIS IN RADIOENGINEERING SPHERE
}

\begin{abstract}
The present article is an attempt to conduct needs analysis of English learners in Radio Engineering sphere. The relevance of the topic is explained by the growing need for ESP programs tailored to specific learners` needs. Needs analysis is defined as an information gathering and interpreting process aimed at curriculum design or modification to better suit the learners`needs. Authors propose an overview of the current approaches to Needs Analysis and its constituent parts. The results of a questionnaire conducted among the students of Radio Technical Faculty, National Technical University of Ukraine "Igor Sikorsky Kyiv Polytechnic Institute", are presented and discussed. The results seem to emphasize the growing need of students to concentrate on IT topics of study as well as to introduce modern IT tools of teaching and learning. Thus, most students need to use English at work and during communication in the spheres of Electronics and IT. The majority of them expect to improve speaking and translation skills while they view most difficulties in speaking and writing. Most students seem to be quite motivated to study ESP and prefer to do it in a small group. In the light of transformation of study because of massive use of IT technologies and the Internet, the respondents largely view the role of a teacher as a language source and a facilitator rather than traditional person responsible for class study. The conducted analysis allowed to reveal the potential spheres and situations of the use of English by students, students`strengths and weaknesses in the language use, their motivation and interests concerning English study, their preferences as for the mode of study and priorities in ESP reading, writing, listening and speaking. The ongoing needs analysis is the prospect of the further research in the field.
\end{abstract}

Keywords: ESP; Needs Analysis; English for Radio Engineering.

\section{INTRODUCTION}

Statement of the problem. The development of the global labour market, information technologies and the emergence of abundant staff exchange programs have made it possible for employees to work abroad and gain experience of working in English-speaking environment. With these possibilities open, there is a growing need for tailored and welldeveloped ESP courses which will provide students with necessary knowledge and skills of the English language use in their field of professional activity. In many technical tertiary and vocational schools in Ukraine and abroad there is a shift from teaching General English to ESP teaching which is explained by the demands of labour market for the employees to speak English as well as by the specificity of fields of study and working activities which inevitably influence the way of language use at work. Considering all these changes and tendencies, the universities face the problem of special ESP programs development for students majoring in many subjects. The first stage and the vital part of such programs development is needs analysis.

Analysis of recent research and publications. The emergence of needs analysis began with Munby`s work "Communicative Syllabus Design" [1], where the author defined and analyzed communicative needs of learners. The subsequent development of communicative 
language teaching and its adoption by the Council of Europe contributed to the acknowledgement of needs analysis and its penetration into syllabus design in the European countries and worldwide. Much work has been done to define the procedure of information gathering during needs analysis, starting with detailed Munby`s Communicative Needs Processor. At present the research into needs assessment continues in the sphere of ESP. Thus, Md. J. Hossain conducted needs analysis for Engineering students [2], S. Adnan investigated needs analysis in Administration [3], S. A. Boroujeni`s object of research was needs analysis of students of Educational Administration [4], etc. Although there is a trend for growing number of researches into ESP needs analysis, there are no specific data on the needs analysis from radio engineering perspective.

The purpose of the article. This study aims at discovering specific Radio Engineering students` needs, analyzing them and interpreting the results in connection with the practical lessons and the use of Information Technologies.

\section{THE THEORETICAL BACKGROUNDS}

Defined by D. Brown [5] as "the activities involved in gathering information that will serve as the basis for developing a curriculum that will meet the learning needs of a particular group of learners", the notion of needs analysis acts rather as an umbrella term to define the survey and interpretation of data obtained from special sources (learners themselves, teachers, administration, employees) concerning learners` lacks, objectives, and wants about the learning process. There are several approaches to the way of conducting needs analysis.

As proposed by K. Westerfield [6], needs assessment involves "conducting a Target Situation Analysis (what the learner needs to be able to do with the language in the future), a Present Situation Analysis (what the learner can do with the language now), and a Context Analysis (what is the environment in which the learning will take place)". Simple and applicable as it may seem, this categorization lacks analysis of the learners ' needs concerning the way of teaching and learning (e.g. preferred organization of work in a group, way of material presentation, learning style, use of Information Technologies etc.), as well as the deeper insight into the language material which should be worked on during lessons.

According to Duddley-Evans and St. John, as cited in S.Otilia [7], the components of needs analysis include five areas such as Target Situation Analysis and Objective Needs Analysis; Present Situation Analysis; Linguistic Analysis, Discourse Analysis, Genre Analysis; Subjective Needs Analysis (subjective factors that affect the way students learn); Means Analysis (focusing on the environment where the students learn). If we compare this system to the previous one, we will see that it proposes two principally new spheres of analysis, namely Subjective Needs Analysis and Linguistic Analysis. The former is very important as it focuses on taking into account such important factors as, for example, style of learning, previous language experience, preferences for material presentation (for example, using the Internet or computer tools) etc. - things that make learning individual, separating a particular person`s needs from common to a group of learners needs. The individualized learning, in turn, proved to be effective in terms of teaching ESP, in particular, teaching ESP writing [8]. The latter sphere - Linguistic Analysis - plays vital role in choosing particular texts and linguistic means for study. This helps to prevent students from wasting time learning material which is not exactly relevant to their professional needs and to prioritize and focus on developing necessary linguistic skills. As for Means Analysis, it obviously corresponds to Westerfield`s Context Analysis, because both of them try to analyze the environment of learning.

M. H. Songhori [9] presents an overview of several approaches to needs analysis which include Target Situation Analysis, Present Situation Analysis, Pedagogic Needs Analysis 
(Deficiency Analysis, Strategy Analysis or Learning Needs Analysis, Means Analysis), Register analysis, Discourse analysis, and Genre Analysis. We can see that the term Pedagogic Needs Analysis was introduced to provide a deeper insight into such constituents as deficiency analysis (lacks, problems that students may experience during learning process, the gap between present and target level of skills mastery) and strategy analysis (learners conception of learning, their own view of how they want to study, strategy and style of learning). This system of approaches seems to us the most exhaustive and we will adopt it in our practical investigation described further.

\section{METHODS}

In order to practically establish students` needs and wants, we conducted needs analysis at Radio Technical Faculty of National Technical University of Ukraine "Igor Sikorsky Kyiv Polytechnic Institute". The analysis was held in form of a questionnaire proposed to students during the second semester of the academic year 2016-2017. 107 students from the second to the fifth year of study participated in the anonymous questionnaire. We agree with S. Adnan [3] that such students are "able to figure their needs and wants since they experienced the ESP course at the first year".

The respondents were asked to answer 14 questions of the questionnaire covering Target Situation Analysis, Present Situation Analysis, Pedagogic Needs Analysis and Linguistic Analysis. They were allowed to choose multiple answers if several options appealed to them. The results of the questionnaire are presented and discussed below.

\section{FINDINGS}

The first part of the questionnaire dealt with the Target Situation Analysis (see Table 1)

Table 1.

\section{Target Situation Analysis}

1. What do you need English for?

\begin{tabular}{|l|c|l|c|}
\hline $\begin{array}{l}\text { a. For } \\
\text { communication. }\end{array}$ & $67(63 \%)$ & d. For personal development & $38(36 \%)$ \\
\hline $\begin{array}{l}\text { b. For work. } \\
\text { c. For study. }\end{array}$ & $83(78 \%)$ & $\begin{array}{l}\text { e. For settling down in a foreign } \\
\text { country. }\end{array}$ & $33(31 \%)$ \\
\hline
\end{tabular}

2. How will the language be used?

\begin{tabular}{|l|c|l|c|}
\hline \begin{tabular}{l} 
a. $\begin{array}{l}\text { Face to face } \\
\text { communication. }\end{array}$ \\
\hline $\begin{array}{l}\text { c. } \text { Telephone } \\
\text { conversations. }\end{array}$
\end{tabular} & $77(72 \%)$ & $\begin{array}{l}\text { b. Reading and searching } \\
\text { information in English. }\end{array}$ & $79(74 \%)$ \\
\hline
\end{tabular}

3. What will the content areas be?

\begin{tabular}{|l|c|c|c|}
\hline a. $\begin{array}{l}\text { Everyday } \\
\text { communication }\end{array}$ & $58(54 \%)$ & b. General Engineering & $22(21 \%)$ \\
\hline $\begin{array}{l}\text { c. } \begin{array}{l}\text { Business } \\
\text { Communication }\end{array} \\
\text { e. Electronics }\end{array}$ & $34(32 \%)$ & d. Mechanical Engineering & $17(16 \%)$ \\
\hline
\end{tabular}




\begin{tabular}{|l|c|c|c|}
\hline $\begin{array}{l}\text { g. } \text { Materials } \\
\text { Engineering }\end{array}$ & $20(19 \%)$ & h. Telecommunication & $44(41 \%)$ \\
\hline $\begin{array}{l}\text { i. } \begin{array}{l}\text { Electrical } \\
\text { Engineering }\end{array} \\
\text { k. } \text { Medicine }\end{array}$ & $47(44 \%)$ & j. TV \& Radio broadcasting & $37(35 \%)$ \\
\hline
\end{tabular}

4. What do you anticipate from English course?

\begin{tabular}{|l|l|l|l|}
\hline $\begin{array}{l}\text { a. To improve } \\
\text { listening skills. }\end{array}$ & $56(52 \%)$ & $\begin{array}{l}\text { b. To improve skills of } \\
\text { translation. }\end{array}$ & $62(60 \%)$ \\
\hline $\begin{array}{l}\text { c. To improve writing } \\
\text { skills. }\end{array}$ & $51(48 \%)$ & d. To learn vocabulary. & $38(36 \%)$ \\
\hline $\begin{array}{l}\text { e. To improve } \\
\text { speaking skills. }\end{array}$ & $80(75 \%)$ & f. To learn grammar. & $29(27 \%)$ \\
\hline $\begin{array}{l}\text { g. To improve reading } \\
\text { skills. }\end{array}$ & $44(41 \%)$ & h. To pass an exam. & $13(12 \%)$ \\
\hline
\end{tabular}

It was found out that most of the respondents needed English for work (78\%) and communication (63\%). Students also found it possible to use English during travelling (51\%), and for study (38\%). Finally, English speaking skills are useful for personal development (as $36 \%$ of respondents believe) and for settling down in a foreign country (31\%). Next, most students agreed that they would use English while reading and searching for information (which mostly happens in English-language Internet environment) and in face to face communication ( $74 \%$ and $72 \%$ respectfully), half of the respondents plan to use English in emailing and written communication and only a quarter - during telephone conversations. The third question investigated the most needed content areas of English, which turned out to be Electronics (56\%), Information Technology and Everyday Communication (54\% each). Electrical Engineering (44\%), Telecommunication (41\%), TV \& Radio broadcasting (35\%) and Business Communication (32\%) also seem to be quite relevant, while other spheres (General Engineering, Materials Engineering, Mechanical Engineering, Safety at Work and Medicine) were of interest to barely a fifth part of the respondents. It is important to stress that ICT sphere nowadays plays a vital role in the spheres of English use, and it has become a truly cross-disciplinary field, needed by engineers, developers, medicine workers, system analysts etc. This is explained by the penetration of the ICT in everyday life as well as in the working environment. Thus, being able to communicate in the sphere of ICT is a skill necessary for modern specialists.

Dealing with the question about anticipations from English course, most respondents (75\%) voted for improving speaking skills. However, a good number of students also admitted the importance of improving translation skills $(60 \%)$, listening skills $(52 \%)$ and writing skills (48\%). Students seemed to be least enthusiastic about learning vocabulary $(36 \%)$ and grammar (2\%). A good sign is that only $12 \%$ of students wanted only to pass exam.

The second part of the questionnaire investigated the present Situation as shown in Table 2.

Table 2.

\section{Present Situation Analysis}

5. How do you assess your proficiency in language skills?

\begin{tabular}{|l|l|l|l|l|}
\hline $\begin{array}{l}\text { a. Speaking } \\
\text { skills }\end{array}$ & $\begin{array}{l}\text { Excellent } \\
5(5 \%)\end{array}$ & $\begin{array}{l}\text { Good } \\
22(21 \%)\end{array}$ & $\begin{array}{l}\text { Satisfactory } \\
47(45 \%)\end{array}$ & Weak \\
\hline b. Reading & Excellent & Good & Satisfactory & Weak \\
\hline
\end{tabular}




\begin{tabular}{|l|l|l|l|l|}
\hline skills & $15(14 \%)$ & $50(47 \%)$ & $35(34 \%)$ & $5(5 \%)$ \\
\hline c. Writing & Excellent & Good & Satisfactory & Weak \\
skills & $2(2 \%)$ & $28(27 \%)$ & $49(47 \%)$ & $25(24 \%)$ \\
\hline $\begin{array}{l}\text { d. Listening } \\
\text { skills }\end{array}$ & Excellent & Good & Satisfactory & Weak \\
\hline $\begin{array}{l}\text { e. Translation } \\
\text { skills }\end{array}$ & Excellent & $43(41 \%)$ & $40(38 \%)$ & $13(12 \%)$ \\
\hline
\end{tabular}

6. Are you interested in taking ESP course?

\begin{tabular}{|l|l|l|l|}
\hline a. Very interested & $24(22 \%)$ & b. Not much & $26(24 \%)$ \\
\hline c. Interested & $53(52 \%)$ & d. Not at all & $2(2 \%)$ \\
\hline
\end{tabular}

While assessing their strengths and weaknesses in language skills students seemed to be most confident in their reading skills (14\% assessed them as excellent, $47 \%$ as good). Most of them also felt that their listening and translation skills were at a good level $(8 \%$ of students voted for excellent listening skills, $41 \%$-for good, excellent translation skills received $7 \%$ of the votes and good $-41 \%)$. Respectively, students had most difficulties with speaking (29\%) and writing skills ( $24 \%$ of the respondents). This part of the interview illustrates the spheres teachers should pay more attention to - in our case, this is the development of communicative competence in speaking and writing. It is obvious, that students' weaknesses lie in the productive skills which require special efforts to shape the thoughts into the form of speech, while receptive skills associated with information perception seem to be easier to develop.

After the analysis of students' motivation to language learning we found out that the majority of students expressed interest in the study (52\%). Almost a quarter of students were very motivated $(22 \%)$, a slightly bigger number of students $(24 \%)$ did not feel much of the interest and only $2 \%$ of the respondents answered that they were not interested in the language study. The survey reveals that, in spite of the fact that the majority of students are motivated, there still is a quarter of students who lack motivation. The reasons behind it may be different; however, the measures should be taken to draw students` interest to the subject. This may be done through applying interesting tasks, modelling professionally oriented situations, using games and creative methods of teaching.

The next part of the questionnaire dealt with the Pedagogic Needs Analysis and focused mostly on students 'preferences to the mode and the way of study, among which - the use of ICT tools in the classroom (see Table 3).

Table 3.

\section{Pedagogic Needs Analysis}

7. In your opinion, how important is ESP course if compared with other subjects?

\begin{tabular}{|l|l|}
\hline a. More important than other subjects. & $16(15 \%)$ \\
\hline b. As important as other subjects. & $74(71 \%)$ \\
\hline c. Less important than other subjects. & $15(14 \%)$ \\
\hline
\end{tabular}

8. How would you like to study?

\begin{tabular}{|l|l|l|l|}
\hline a. Individually & $35(33 \%)$ & b. In a small group & $81(76 \%)$ \\
\hline c. In a pair & $15(14 \%)$ & d. In a large group & $5(5 \%)$ \\
\hline
\end{tabular}

9. How do you like material to be presented?

\begin{tabular}{|l|l|}
\hline a. In form of a text, written rules and explanations. & $41(38 \%)$ \\
\hline b. In form of pictures, animated illustrations, videos, diagrams etc. & $59(55 \%)$ \\
\hline c. In form of audio record, oral explanations, videos. & $46(43 \%)$ \\
\hline d. In form of practical tasks which involve your experience. & $47(44 \%)$ \\
\hline
\end{tabular}


10. What kind of role do you like your teacher to have?

\begin{tabular}{|l|c|l|c|}
\hline a. Role of a facilitator and guide. & $39(36 \%)$ & $\begin{array}{l}\text { b. Role of a manager and } \\
\text { planner }\end{array}$ & $30(28 \%)$ \\
\hline $\begin{array}{l}\text { c. Traditional role of a someone in } \\
\text { control of everything in a class }\end{array}$ & $23(22 \%)$ & $\begin{array}{l}\text { d. Language and knowledge } \\
\text { resource }\end{array}$ & $52(49 \%)$ \\
\hline
\end{tabular}

As the first question revealed, the majority of students (71\%) had adequate attitude toward ESP lessons as equal in importance with the other subjects. The rest of the opinions divided almost in half: $15 \%$ of the students thought that ESP was even more important while $14 \%$ of them believed that it was less important than other subjects. As for the preferences in the mode of study, most students would like to study in a small group (76\%), a third individually, and a small part (14\%) - in a pair. Only $5 \%$ of respondents expressed a desire to study in a large group. The results of the next question showed students " preference in the presentation of the material using ICT tools. Thus, it became clear that most respondents $(55 \%)$ have prevailing visual channel of information perception and prefer animated and illustrated material. A large number of students $(44 \%$ and $43 \%)$ would like material to be presented through audio channel, or practically, engaging their personal experience. The classic textual presentation received the least number of votes $(38 \%)$, which is probably explained by the abundance and appeal of multimedia means of teaching which outperform textual means. This leads us to conclusion that one of the effective ways of satisfaction of student's preferences as for the mode of material presentation is the incorporation of ICT in the classroom. Interactive whiteboards, access to online-testing, multimedia presentations are only several examples how a traditional material can be turned into interactive one, adding value to the efficacy of study.

A change from the classic model to the modern one can also be traced in the perception of a teacher's role in the class. Thus, half of the students $(49 \%)$ see the teacher as language and knowledge source, $36 \%$ of the respondents see the teacher as a facilitator and a guide. Only $22 \%$ voted for the traditional role of someone in control of everything in the class, which clearly expresses students` readiness to share the responsibility for the results of their study.

The last part of the questionnaire was dedicated to the Linguistic Analysis and aimed at defining the priorities of the students in different genres of professionally-oriented English. The detailed results of this part are shown in Table 4.

Table 4.

\section{Linguistic Analysis}

11. What are your priorities in ESP reading?

\begin{tabular}{|l|l|l|l|}
\hline & Priority & Important & Not important \\
\hline Manuals \& Instructions & $38(36 \%)$ & $54(50 \%)$ & $15(14 \%)$ \\
\hline Patents \& Specifications & $26(24 \%)$ & $54(50 \%)$ & $25(23 \%)$ \\
\hline Specialist literature & $53(50 \%)$ & $46(43 \%)$ & $10(9 \%)$ \\
\hline Contracts \& legal documents & $26(24 \%)$ & $43(40 \%)$ & $36(34 \%)$ \\
\hline Business correspondence & $25(23 \%)$ & $42(39 \%)$ & $40(37 \%)$ \\
\hline Other (please specify) & $15(14 \%)$ & $47(44 \%)$ & $26(24 \%)$ \\
\hline
\end{tabular}

12. What are your priorities in ESP writing?

\begin{tabular}{|l|l|l|l|}
\hline & Priority & Important & Not important \\
\hline Instructions & $42(39 \%)$ & $47(44 \%)$ & $15(14 \%)$ \\
\hline Reports & $21(20 \%)$ & $59(55 \%)$ & $23(22 \%)$ \\
\hline Business letters & $32(30 \%)$ & $42(39 \%)$ & $31(29 \%)$ \\
\hline
\end{tabular}




\begin{tabular}{|l|l|l|l|}
\hline Articles & $36(34 \%)$ & $43(40 \%)$ & $27(25 \%)$ \\
\hline E-mails & $38(36 \%)$ & $51(48 \%)$ & $16(15 \%)$ \\
\hline Abstracts & $15(14 \%)$ & $64(60 \%)$ & $28(26 \%)$ \\
\hline Memorandums & $11(10 \%)$ & $32(30 \%)$ & $65(61 \%)$ \\
\hline CVs & $43(40 \%)$ & $41(28 \%)$ & $24(22 \%)$ \\
\hline Other (please specify) & $12(11 \%)$ & $25(23 \%)$ & $46(43 \%)$ \\
\hline
\end{tabular}

13. What are your priorities in ESP speaking ?

\begin{tabular}{|l|l|l|l|}
\hline & Priority & Important & Not important \\
\hline Small talk & $48(45 \%)$ & $49(46 \%)$ & $12(11 \%)$ \\
\hline Speaking to colleagues & $55(51 \%)$ & $41(38 \%)$ & $9(8 \%)$ \\
\hline Speaking on the phone / via Skype & $39(36 \%)$ & $53(50 \%)$ & $13(12 \%)$ \\
\hline Taking part in meetings & $38(36 \%)$ & $48(45 \%)$ & $19(18 \%)$ \\
\hline Giving presentations & $29(27 \%)$ & $58(54 \%)$ & $20(19 \%)$ \\
\hline Giving instructions / consultations & $37(35 \%)$ & $50(47 \%)$ & $20(19 \%)$ \\
\hline Other (please specify) & $9(8 \%)$ & $25(23 \%)$ & $49(46 \%)$ \\
\hline
\end{tabular}

14. What are your priorities in ESP listening?

\begin{tabular}{|l|l|l|l|}
\hline & Priority & Important & Not important \\
\hline Lectures and presentations & $61(57 \%)$ & $42(39 \%)$ & $4(4 \%)$ \\
\hline Reports & $26(24 \%)$ & $62(58 \%)$ & $19(18 \%)$ \\
\hline Instructions & $40(37 \%)$ & $55(51 \%)$ & $10(9 \%)$ \\
\hline News & $45(42 \%)$ & $44(41 \%)$ & $17(16 \%)$ \\
\hline Explanations and descriptions & $33(31 \%)$ & $56(52 \%)$ & $18(17 \%)$ \\
\hline Other (please specify) & $11(10 \%)$ & $24(22 \%)$ & $24(22 \%)$ \\
\hline
\end{tabular}

Thus, students priorities in ESP reading include specialist literature, manuals, instructions, patents and specifications, most genres being connected with ICT. Of little importance to them are legal documents and business correspondence. As for the ESP writing, the respondents would most like to have competence in writing CVs, instructions, abstracts and reports, memorandums being of little interest to them. As the questionnaire showed, the priority spheres of speaking are speaking to colleagues, giving presentations and speaking on the phone. In the listening part, the most important spheres are lectures, presentations and reports.

\section{CONCLUSIONS AND PROSPECTS FOR FURTHER RESEARCH}

As stated by S.M. Otilia [7], "needs analysis is the foundation on which we can develop curriculum content, teaching materials and methods that can lead to increasing the learners 'motivation and success." Having conducted needs analysis at Radio Technical Faculty we received a deeper insight into the student's needs and wants concerning English study. The obtained picture revealed the potential spheres and situations of the use of English by students, students` strengths and weaknesses in the language use, their motivation and interests concerning English study, their preferences as for the mode of study and priorities in ESP reading, writing, listening and speaking. Of particular interest are the results connected with the use of ICT in the classroom and study process. Students largely prefer presentation of material using different computer tools, be it presentations, animated video etc. The abundance of information on the Internet has partly led to the change in the role of a teacher 
in the class, making it the role of a facilitator rather than the sole source of knowledge. It is also obvious that the topics connected with information technologies are in demand among students. They want to study English for IT, be able to write e-mails, manuals, instructions etc. All these data can surely contribute to the curriculum development and the general increase of the quality of study. However, we cannot but agree with S. Adnan [3] that "an ongoing needs analysis is highly recommended for students since the aim of an ESP program is to cope with the changing needs of the learners". So, the prospects of the study are connected with the analysis of needs of next years`students and with the application of the obtained information in the teaching process.

\section{REFERENCES (TRANSLATED AND TRANSLITERATED):}

[1] J. Munby, Communicative syllabus design. Cambridge: Cambridge University Press, 1978. (in English).

[2] M. J. Hossain, "ESP A Needs Analysis for Engineering Students: A Learner Centered Approach," Journal of PU, Part B, Vol. 2, No. 2, July 2013, pp. 16-26, 2013. (in English).

[3] S. Adnan, "Needs Analysis: A Process to Improve the Learning of ESP at the College of Administration - The Department of Administration and Economy - University of Basra," The Arab Gulf, Vol. 15, issue 3-4, pp. 1-20, 2012. (in English).

[4] S. A. Boroujeni, F. M. Fard, "A Needs Analysis of English for Specific Purposes (ESP) Course For Adoption Of Communicative Language Teaching : (A Case of Iranian First-Year Students of Educational Administration)," International Journal of Humanities and Social Science Invention ISSN, Volume 2 Issue 6, June 2013, pp. 35-44, 2013. (in English).

[5] D. Brown, The Elements of Language Curriculum: A Systematic Approach to Program Development. New York: Heinle and Heinle, 1995. (in English).

[6] K. Westerfield, An overview of needs assessment in English for specific purposes, Best Practices in ESP E-Teacher Course. Oregon: University of Oregon, pp. 1-6, 2010. (in English).

[7] S. M. Otilita, "Needs Analysis in English for Specific Purposes," Annals of the „Constantin Brâncuşi”" University of Târgu Jiu, Economy Series, Issue 1, volume II/2015, pp. 54-55, 2015. (in English).

[8] Yu. Baklazhenko, Methodology of Individualized Teaching of Professionally Oriented Written English Language to Future System Analysts, Ph.D. dissertation, Kyiv National Linguistic University, 2016. (in Ukrainian).

[9] M. H. Songhori, "Introduction to Needs Analysis". English for Specific Purposes world, Issue 4, pp. 1014, 2008. (in English).

Text of the article was accepted by Editorial Team 22.02.2018

\section{АНАЛІЗ ПОТРЕБ МАЙБУТНІХ РАДІОІНЖЕНЕРІВ У НАВЧАННІ АНГЛІЙСЬКОї МОВИ}

\section{Баклаженко Юлія Вікторівна}

кандидат педагогічних наук, доцент кафедри англійської мови гуманітарного спрямування №3 Національний технічний університет України «Київський політехнічний інститут імені Ігоря Сікорського», м. Київ, Україна ORCHID ID 0000-0002-9035-7737

julia_pavlovska@ukr.net

\section{Савчук Тетяна Леонідівна}

викладач кафедри англійської мови гуманітарного спрямування №3

Національний технічний університет України «Київський політехнічний інститут імені Ігоря Сікорського», м. Київ, Україна

\footnotetext{
Анотація. Стаття присвячена проблемі аналізу потреб у навчанні англійської мови майбутніх радіоінженерів і ролі інформаційних технологій серед цих потреб. Актуальність проблеми пояснюється необхідністю розробки програм для навчання професійно орієнтованої англійської мови, які задовольняли б потреби студентів, характерні для певної сфери діяльності. Аналіз потреб визначається як процес збору й аналізу даних, метою якого
} 
є розробка або переробка навчальних програм для кращої відповідності потребам студентів. У статті пропонується аналіз наявних підходів до аналізу потреб і його складових. Представлено результати опитування, проведеного серед студентів Радіотехнічного факультету Національного технічного університету України «Київський політехнічний інститут імені Ігоря Сікорського». Результати опитування показали, що більшість студентів використовують або планують використовувати англійську мову у сфері електроніки й інформаційних технологій. Студенти мають потребу в удосконаленні умінь говоріння $\mathrm{i}$ перекладу, у той час, як найскладнішими для них $є$ уміння говоріння і письма. Більшість студентів є мотивованими до навчання професійно орієнтованої англійської мови й надають перевагу навчанню у невеликих групах. Респонденти вбачають роль викладача як помічника в навчанні і джерела знань 3 мови. Цікавими $\epsilon$ результати, що стосуються використання інформаційних технологій на заняттях і в процесі навчання. Студенти в більшості надають перевагу поданню матеріалу з використанням комп'ютерних засобів, будь то мультимедійні презентації, відео та ін. Також очевидною є потреба студентів у вивченні матеріалу, пов'язаного 3 інформаційними технологіями: серед важливих тем, на думку студентів, представлена англійська для інформаційних технологій, серед жанрів, якими прагнуть оволодіти студенти - електронні листи, інструкції, керівництво. Проведений аналіз дозволив виявити потенційні сфери і ситуації використання англійської мови студентами, їхні сильні і слабкі сторони у використанні мови, мотивацію й інтереси у навчанні англійської мови, їхні вподобання стосовно режиму навчання і пріоритети у читанні, письмі, говорінні й аудіюванні професійно орієнтованої англійської мови. Подальший аналіз потреб у навчанні англійської мови у різних сферах $є$ перспективою наступних досліджень.

Ключові слова: англійська мова професійного спрямування; аналіз потреб; англійська для радіоінженерів.

\section{АНАЛИЗ ПОТРЕБНОСТЕЙ БУДУЩИХ РАДИОИНЖЕНЕРОВ В ИЗУЧЕНИИ АНГЛИЙСКОГО ЯЗЫКА}

\section{Баклаженко Юлия Викторовна}

кандидат педагогических наук, доцент кафедры английского языка гуманитарного направления №3 НТУ Украины «Киевский политехнический институт имени Игоря Сикорского», г. Киев, Украина ORCHID ID 0000-0002-9035-7737 julia_pavlovska@ukr.net

\section{Савчук Татьяна Леонидовна}

преподаватель кафедры английского языка гуманитарного направления №3

НТУ Украины «Киевский политехнический институт имени Игоря Сикорского», г. Киев, Украина

Аннотация. Статья посвящена проблеме анализа потребностей в изучении английского языка будущих радиоинженеров и роли информационных технологий среди этих потребностей. Актуальность проблемы объясняется необходимостью разработки программ для обучения профессионально ориентированному английскому языку, которые удовлетворяли бы потребности студентов, характерные для определенной сферы деятельности. Анализ потребностей определяется как процесс сбора и анализа данных, целью которого является разработка и переработка учебных программ для лучшего соответствия потребностям студентов. В статье предлагается анализ имеющихся подходов к анализу потребностей и их составляющих. Представлены результаты опроса, проведенного среди студентов радиотехнического факультета Национального технического университета Украины «Киевский политехнический институт имени Игоря Сикорского». Результаты опроса показали, что большинство студентов используют или планируют использовать английский язык в сфере электроники и информационных технологий. Студенты нуждаются в совершенствовании умений говорения и перевода, в то время как самыми сложными для них является умения говорения и письма. Большинство студентов являются мотивированными к изучению профессионально ориентированного английского языка и предпочитают учиться в небольших группах. Респонденты видят роль преподавателя как помощника в учебе и источника знаний по языку. Интересными являются результаты, 
касающиеся использования информационных технологий на занятиях и в процессе обучния. Студенты в большинстве предпочитают представление материала с использованием компьютерных средств, будь то мультимедийные презентации, анимированное видео и пр. Также очевидной является потребность студентов в изучении материала, связанного с информационными технологиями: среди затребованных тем представлен английский для информационных технологий, среди жанров, которыми стремятся овладеть студенты электронные письма, инструкции, руководства. Проведенный анализ позволил выявить потенциальные сферы и ситуации использования английского языка студентами, их сильные и слабые стороны в использовании языка, мотивацию и интересы в обучении английскому языку, их предпочтения относительно режима обучения и приоритеты в чтении, письме, говорении и аудировании профессионально ориентированного английского языка. Дальнейший анализ потребностей в обучении английскому языку в различных сферах является перспективой последующих исследований.

Ключевые слова: английский язык профессионального направления; анализ потребностей; английский для радиоинженеров.

\section{(cc) BY-NC-SA}

This work is licensed under Creative Commons Attribution-NonCommercial-ShareAlike 4.0 International License. 